\title{
Pendapatan dan Risiko Produksi Usahatani Pacar Air (Impatiens balsamina Linn) pada Musim Hujan dan Kemarau di Subak Saradan, Desa Sibang Gede, Kecamatan Abiansemal, Kabupaten Badung
}

\author{
I MADE JUNI ADITYA, I WAYAN WIDYANTARA, \\ PUTU UDAYANI WIJAYANTI
}

\author{
Program Studi Agribisnis, Fakultas Pertanian, Universitas Udayana \\ J1. PB. Sudirman Denpasar 80232 \\ Email: joooniehaditya@yahoo.com \\ widyantaramkr@yahoo.com
}

\begin{abstract}
Income and Production Risk of Pacar Air(Impatiens balsamina Linn)Farm in Rainy and Dry Season in Saradan Subak, Sibang Gede Village, Abiansemal, Badung Regency
\end{abstract}

Flower use rate in Bali equals to farmer's interest to produce flowers. This phenomenon becomes the reason for Subak Saradan's farmer trying changing the half of their field in rainy and dry season to plant impatiens flower in order to fulfil the needs of market of their products.

The aims of this research is to know which season are best to plant impatiensflower observed from the differences in income and risk in rainy and dry season. Variables in this research are farming analysis and Subak Saradan's risk level. These variables are analysed using quantitative method.

The result of this research shows that impatiens flower farming in dry season is better than in the rainy season. The income of the farmers in this season is $\mathrm{Rp}$ 532,287,522. More than total income in rainy season that is $\mathrm{Rp} 388,338,689$. Indicator that is used to measure the risk level in rainy and dry season in this research is variation coefficient with each values are 0.57 and 0.50 . The value of the coefficient in rainy season is higher than the dry season. Hence, the risk of failing is higher in this season.

This research also projecting the income of the farmers that are burdened with production risk level in the planting season. The average value of respondent's income based on their land size and risk of the seasons are $\mathrm{Rp} 1,574,044.33$ and $\mathrm{Rp} 3,601,044.01$. In some condition with the highest risk, could make $20,9 \%$ respondents in rainy season and $14,5 \%$ respondents in dry season may suffer loss.

Keywords: income, risk, rainy season, dry season 


\section{Pendahuluan}

\subsection{Latar Belakang}

Indonesia merupakan negara agraris yang sebagian besar penduduknya bekerja pada sektor pertanian. Sekitar sebanyak 38 juta penduduk atau $48 \%$ dari jumlah penduduk Indonesia bekerja pada sektor pertanian dengan rata-rata kepemilikan lahan seluas 0,34 ha (Budiasa, 2011). Berbanding lurus dengan daya serap tenaga kerja Indonesia ke sektor pertanian, sektor ini memiliki peranan besar dalam pembentukan Produk Domestik Bruto (PDB) sebesar Rp 327,7 Triliun atau sekitar $13 \%$ dari total PDB Indonesia pada tahun 2010 s.d 2014 (BPS, 2015). Namun demikian kehidupan mayoritas petani di Indonesia masih belum berada pada kategori sejahtera, hal ini disebabkan oleh tingginya risiko kerugian yang sering diterima petani daripada pendapatan yang diharapkan.

Kehidupan mayoritas masyarakat Bali beragama Hindu tidak dapat lepas dari konsumsi bunga sebagai salah satu sarana wajib persembahyangan setiap harinya. Tingginya konsumsi bunga di Bali diimbangi juga oleh minat produksinya. Bunga pacar air merupakan salah satu jenis bunga yang banyak digunakan. Fenomena ini menjadi alasan petani di Subak Saradan mengusahakan sebagian bahkan seluruh lahan tani yang digarapnya untuk mengusahakan tanaman bunga pacar air guna memenuhi kebutuhan dan mendapat pasar setiap hari bagi produknya.

Keberadaan musim tanam bunga pacar air dapat dilihat pada musim hujan maupun kemarau di Subak Saradan, Desa Sibang Gede, Kecamatan Abiansemal, Kabupaten Badung. Kegiatan usahatani bunga pacar air dilakukan sepanjang musim dengan alasan masa panen dapat dilakukan setiap hari selama dua bulan terus menerus mulia dari bulan kedua setelah penanaman, sehingga pendapatan dapat diperoleh dari hasil penjualan setiap harinya juga. Pasar yang relatif selalu ada menjadikan komoditas ini sebagai primadona bagi petani Subak Saradan.

Perbedaan kondisi pada musim hujan dan kemarau mempengaruhi besar kecilnya produksi serta peneriman yang diperoleh oleh petani bunga pacar air, selain itu perbedaan musim juga memberi tingkat risiko yang berbeda(Suharyanto dan Arya. 2015). Pernyataan tersebut menjadi menarik untuk diteliti, bagaimana perbandingan pendapatan dan risiko produksi usahatani pacar air pada musim hujan dan kemarau di Subak Saradan, Desa Sibang Gede, Kecamatan Abiansemal, Kabupaten Badung. Penelitian berguna untuk mengetahui musim yang lebih baik dipergunakan dalam melakukan usahatani bunga pacar air dilihat dari perbedaan pendapatan dan tingkat risiko usahatani pada musim hujan dan kemarau.

\subsection{Tujuan Penelitian}

Tujuan dari dilakukannya penelitian adalah untuk mengetahui.

1. Perbandingan pendapatan usahatani pacar air pada musim hujan dengan kemarau di Subak Saradan.

2. Perbandingan tingkat risiko usahatani pacar air pada musim hujan dan kemarau di Subak Saradan. 
3. Nilai pendapatan usahatani pacar yang dibebani risiko pada musim hujan dan kemarau di Subak Saradan.

\section{Metodologi Penelitian}

\subsection{Tempat dan Waktu Penelitian}

Penelitian dilaksanakan di Subak Saradan, Desa Sibang Gede, Kecamatan Abiansemal, Kabupaten Badung. Penelitian dilaksanakan pada Bulan Februari-Maret 2016. Pemilihan lokasi dilakukan secara sengaja dengan pertimbangan hampir $30 \%$ dari 455 anggota Subak Saradan melakukan usahatani bunga pacar air dan dapat dijumpai sepanjang tahun, baik pada musim hujan maupun kemarau.

\subsection{Metode Pengumpulan Data, data, dan Variabel Penelitian}

Data yang digunakan dalam penelitian pendapatan dan risiko produksi pacar air pada musim hujan dan kemarau di Subak Saradan, Desa Sibang Gede, Kecamatan Abiansemal, Kabupaten Badung bersumber dari data primer yang diperoleh langsung dari hasil observasi dan wawancara, sedangkan data sekunder diperoleh dari studistudi sebelumnya mengenai penelitian terkait. Variabel dalam penelitian ini adalah analisis usahatani dan risiko pada Subak Saradan.

\subsection{Sampel dan Teknik Pengambilan Sampel}

Sampel penelitian diambil dari populasi yang merupakan petani Subak Saradan yang mengusahakan pacar air pada musim hujan dan kemarau. Penentuan jumlah sampel menggunakan metode slovin (Sivellia dalam Suryana, 2007) dengan batas toleransi kesalahan sebesar $10 \%$. Populasi berjumlah 165 orang, dari jumlah populasi tersebut diperoleh jumlah sampel sebanyak 62 orang responden yang akan diproporsi berdasarkan jumlah anggota masing-masing munduk di Subak Saradan.

\subsection{Metode Analisis}

Metode yang digunakan dalam penelitian adalah analisis data, antara lain.

\subsubsection{Penerimaan}

Penerimaan yang diperhitungkan pada penelitian ini adalah penerimaan untuk setiap satu periode musim tanam hujan dan kemarau. Penerimaan usahatani pacar air pada musim hujan dan kemarau dapat diperhitungkan dengan rumus (Hermanto dalam Nasution, 2010).

$$
\mathrm{R}_{\mathrm{m}}=\mathrm{P}_{\mathrm{m}} \cdot \mathrm{Q}_{\mathrm{m}}
$$

Keterangan:

$\mathrm{R}_{\mathrm{m}}=$ Penerimaan masing-masing musim

$\mathrm{P}_{\mathrm{m}}=$ Harga komoditi masing-masing musim

$\mathrm{Q}_{\mathrm{m}}=$ Jumlah komoditi per masing-masing musim 


\subsubsection{Biaya}

Biaya yang diperhitungkan pada penelitian ini adalah biaya untuk setiap satu periode musim tanam hujan dan kemarau. Biaya total dalam usahatani pacar air pada musim hujan dan kemaru dapat dirumuskan sebagai berikut (Hermanto dalam Nasution, 2010).

$$
\mathrm{C}_{\mathrm{m}}=\mathrm{FC}_{\mathrm{m}}+\mathrm{VC}_{\mathrm{m}}
$$

Keterangan:

$\mathrm{C}_{\mathrm{m}}=$ Total Biaya masing-masing musim

$\mathrm{FC}_{\mathrm{m}}=$ Biaya tetap per masing-masing musim

$\mathrm{VC}_{\mathrm{m}}=$ Biaya variabel per masing-masing musim

\subsubsection{Pendapatan}

Pendapatan yang diperhitungkan pada penelitian ini adalah pendapatan untuk setiap satu periode musim tanam hujan dan kemarau.Pendapatan dalam usahatani pacar air pada musim hujan dan kemaru dapat dirumuskan sebagai berikut (Hermanto dalam Nasution, 2010).

$$
\mathrm{X}_{\mathrm{m}}=\mathrm{R}_{\mathrm{m}}-\mathrm{C}_{\mathrm{m}}
$$

Keterangan:

$\mathrm{x}_{\mathrm{mh}}=$ Pendapatan masing-masing musim

$\mathrm{R}_{\mathrm{mh}}=$ Total penerimaan per masing-masing musim

$\mathrm{C}_{\mathrm{mh}}=$ Total biaya per masing-masing musim

\subsubsection{R/C}

$\mathrm{R} / \mathrm{C}$ merupakan rasio atau perbandingan antara tingkat penerimaan dengan biaya yang dikeluarkan pada periode/ musim tanam yang sama. Nilai R/C menunjukkan hubungan untuk setiap penerimaan terhadap biaya yang diperlukannya. $\mathrm{R} / \mathrm{C}$ dapat dirumuskan sebagai berikut (Fidaus, 2010) .

$$
\mathrm{R} / \mathrm{C}=\frac{\mathrm{R}}{\mathrm{C}}
$$

Keterangan:

$$
\begin{array}{ll}
\mathrm{R} / \mathrm{C} & =\text { Rasio penerimaan-biaya } \\
\mathrm{R} & =\text { Penerimaan } \\
\mathrm{C} & =\text { Biaya }
\end{array}
$$

\subsubsection{Risiko}

Perhitungan nilai indikator tingkat risiko diawali dengan pencarian nilai peluang dan harapan produski untuk masing-masing musim, yang dirumuskan sebagai berikut (Darmawi, 2014)

Keterangan:

$$
\mathrm{P}=\frac{\mathrm{f}_{\mathrm{i}}}{\mathrm{n}}
$$

$\mathrm{P} \quad=$ peluang

$\mathrm{f}_{\mathrm{i}} \quad=$ jumlah kejadian $-\mathrm{i}$

$\mathrm{n} \quad=$ jumlah seluruh responden

$$
\mathrm{E}(\mathrm{Q})_{\mathrm{j}}=\sum^{\mathrm{n}}(\mathrm{Pij} \cdot \overline{\mathrm{Q} \mathrm{j}})
$$


Keterangan:

$\mathrm{E}(\mathrm{Q})_{\mathrm{j}} \quad=$ harapan produksi masing-masing muism

$\mathrm{P}_{\mathrm{ij}} \quad=$ peluang masing-masing kondisi dan musim

$\bar{Q}_{\mathrm{ij}} \quad=$ rata-rata produksi bunga pacar air masing-masing kondisi dan musim $(\mathrm{kg})$

Pengukuran tingkat risiko usahatani pacar air pada musim hujan dan kemarau menggunakan perhitungan varian, standar deviasi, dan koefisien variasi.

a. Varian

Nilai varian produksimenunjukan besarnya penyimpangan produksi dari sebaran data yang ada. Nilai varian dapat dituliskan dengan rumus sebagai berikut (Elton dan Guber dalam Purnama, 2012).

$$
\mathrm{s}^{2}{ }_{\mathrm{j}}=\sum^{\mathrm{n}} \operatorname{Pjk}(\mathrm{Qjk}-\overline{\mathrm{Q}})^{2}
$$

Keterangan:

$\mathrm{s}^{2}{ }_{\mathrm{j}} \quad$ = varianmasing-masing musim

$\mathrm{P}_{\mathrm{jk}} \quad$ = peluang masing-masing musim dan sampel

$\mathrm{Q}_{\mathrm{jk}} \quad$ = produksi masing-masing musim dan sampel

$\bar{Q}_{j} \quad$ = rata-rata produksi masing-masing musim

b. Standar deviasi

Nilai standar deviasi produksimenunjukan besarnya penyimpangan produksi dari sebaran data yang ada. Hampir sama dengan varian, namun sebaran data pada standar deviasi lebih kecil sehingga lebih memudahkan pengamatan. Perhitungan untuk standar deviasi adalah sebagai berikut (Elton dan Guber dalamPurnama, 2012).

$$
s_{j}=\sqrt{s^{2}}
$$

Keterangan:

$\mathrm{s}^{2}{ }_{\mathrm{j}} \quad=$ varian masing-masing musim

$\mathrm{s} \quad=$ standar deviasi masing-masing musim

c. Koefisien variasi

Koefisien variasi merupakan ukuran yang bebas dimensi, atau angka murni yang dapat digunakan untuk membandingkan risiko relatif dari dua proyek atau usaha maupun yang lebih dari dua proyek atau usaha. Usaha yang memiliki koefisien variasi paling tinggi adalah usaha yang paling berisiko (Salvatore, 2003). Menurut Elton dan Guber(dalamPurnama 2012), koefisien variasi dirumuskan dengan.

$$
\mathrm{CV}_{\mathrm{j}}=\frac{\mathrm{s}_{\mathrm{j}}}{\mathrm{E}(\mathrm{Q})_{\mathrm{j}}}
$$

Keterangan:

$\mathrm{CV}_{\mathrm{j}} \quad$ = koefisien variasi masing-masing musim

$\mathrm{s}_{\mathrm{j}} \quad=$ standar deviasi masing-masing musim

$\mathrm{E}(\mathrm{Q})_{j} \quad=$ harapan produksi masing-masing musim 


\section{Hasil dan Pembahasan}

\subsection{Karakteristik Responden}

Penelitian dilakukan terhadap petani pengusaha komoditi pacar air di Subak Saradan, Desa Sibang Gede, Kecamatan Abiansemal, Kabupaten Badung. Berdasarkan metode slovin $(\mathrm{e}=10 \%)$, responden berjumlah 62 dari 165 populasi yang diproporsi berdasarkan sebaran populasi pada masing-masing sub-subak. Karakteristik responden penelitian berdasarkan umur, pendidikan, luas lahan dan status kepemilikan lahan dilihat pada Tabel 1.

Tabel 1.

Karakteristik Responden

\begin{tabular}{|c|c|c|c|c|}
\hline \multirow{2}{*}{ No } & \multirow{2}{*}{ Karakteristik } & \multirow{2}{*}{ Kategori } & \multicolumn{2}{|c|}{ Jumlah } \\
\hline & & & Orang & $\%$ \\
\hline \multirow[t]{2}{*}{1} & Umur & Produkstif & 54 & 87,10 \\
\hline & & Tidak produktif & 8 & 12,90 \\
\hline \multirow[t]{6}{*}{2} & Pendidikan & Tidak sekolah & 5 & 8,06 \\
\hline & & $\mathrm{SD}$ & 26 & 41,94 \\
\hline & & SMP & 4 & 6,45 \\
\hline & & SMA & 22 & 35,48 \\
\hline & & Diploma & 1 & 1,61 \\
\hline & & Strata 1 & 4 & 6,45 \\
\hline \multirow[t]{3}{*}{3} & Luas lahan & Sempit & 47 & 75,81 \\
\hline & & Sedang & 13 & 20,97 \\
\hline & & Luas & 2 & 3,22 \\
\hline \multirow[t]{2}{*}{4} & Kepemilikan lahan & Sakap & 17 & 27,42 \\
\hline & & Milik & 45 & 72,58 \\
\hline
\end{tabular}

Mayoritas responden penelitian berada dalam kategori umur produktif, berpendidikan SD, berusahatani pada lahan sempit, dan berstatus pemilik lahan.

\subsection{Perbandingan Pendapatan Usahatani Pacar Air pada Musim Hujan dengan Kemarau di Subak Saradan}

Hasil analisis usahatani yang meliputi penerimaan, biaya, pendapatan dan $\mathrm{R} / \mathrm{C}$ dapat dilihat pada Tabel 2.

Tabel 2.

Rekapitulasi Analisis Usahatani Pacar Air

\begin{tabular}{llrr}
\hline \multirow{2}{*}{ No } & \multicolumn{2}{c}{ Uraian } & \multicolumn{2}{c}{ Musim } \\
\cline { 3 - 4 } & & 44.056 & \multicolumn{1}{c}{ Hujan } \\
\hline 1 & Total produksi (kg/luas tanam) & 12.000 & 12.000 \\
2 & Rata-rata harga (rp/kg) & 561.396 .000 & 719.253 .000 \\
3 & Total penerimaan (rp) & 113.371 .978 & 112.223 .478 \\
4 & Total biaya (rp) & 448.024 .022 & 607.029 .522 \\
5 & Total pendapatan petani (rp) & 4,95 & 6,41 \\
6 & R/C petani & & \\
\hline
\end{tabular}


Penerimaan total pada musim hujan dan kemarau diperoleh dari harga jual terhadap jumlah produksi yang dihasilkan. Nilai total penerimaan 62 responden pada musim hujan dan kemarau masing-masing sebesar Rp561.396.000,00 dan Rp 719.253.000,00.

Nilai biaya total yang telah dibebankan kepada total penerimaan masingmasing musim menghasilkan nilai pendapatan pada masing-masing musim. Pendapatan total usahatani pada musim hujan dan kemarau adalah masing-masing sebesar Rp 448.024.022 dan Rp 607.029.522. Pendapatan petani pada musim kemarau yang lebih tinggi mengindikasikan bahwa usahatani pada musim ini lebih efektif untuk dilakukan di Subak Saradan dilihat dari segi ekonomis.

Rasio perbandingan penerimaan terhadap biaya (R/C) menggambarkan efisiensi suatu pengorbanan terhadap hasil yang diperoleh. Nilai R/C rata-rata pada musim hujan sebesar 4,95 menggambarkan bahwa setiap satu rupiah biaya yang dikeluarkan akan memberi penerimaan sebesar 4,95 rupiah pada musim hujan, sedangkan $\mathrm{R} / \mathrm{C}$ rata pada musim kemarau sebesar 6,41 menggambarkan bahwa setiap satu rupiah biaya yang dikeluarkan akan memberi penerimaan sebesar 6,41 rupiah pada musim kemarau. Musim kemarau yang memiliki R/C rata-rata lebih tinggi menggambarkan bahwa rata-rata usahatani bunga pacar air lebih efisien dilakukan pada musim kemarau dilihat dari tingkat perbandingan penerimaan terhadap biaya.

\subsection{Uji Beda Pendapatan Musim Hujan dan Kemarau}

Berdasarkan perhitungan manual uji t, diperoleh nilai t hitung sebesar -1,608 dan $\mathrm{t}$ tabel 2,000 $(\mathrm{db}=60, \alpha=0,05)$. Nilai t-hitung lebih besar dari t-tabel, yang berarti terima $\mathrm{H}_{0}$ (Siregar 2013). Hipotesis (dugaan) yang dapat digunakan dari penilaian uji beda dengan indikator perbandingan nilai t-hitung dengan t-tabel adalah tidak terdapat perbedaan antara rata-rata pendapatan petani pacar air pada musim hujan dan kemarau.

\subsection{Risiko Produksi Usahatani Pacar Air pada Musim Hujan dan Kemarau di Subak Saradan}

Perhitungan nilai tingkat risiko diawali dengan pencarian nilai peluang dan ekspektasi (harapan) produski untuk masing-masing kondisi pada setiap musim, berikut nilai peluang dan harapan produksi pacar air untuk masing-masing kondisi pada setiap musim. 
Tabel 3.

Probabilitas,Rata-rata, dan Ekspektasi Produksi Pacar Air untuk Masing-masing Kondisipada setiap Musim

\begin{tabular}{lcccc}
\hline Musim & Kondisi & $\begin{array}{c}\text { Probabilitas / } \\
\text { Peluang }\end{array}$ & $\begin{array}{c}\text { Rata-rata Produksi } \\
(\mathrm{kg} / \mathrm{are})\end{array}$ & $\begin{array}{c}\text { Ekspektasi } \\
\text { Produksi (kg/are) }\end{array}$ \\
\hline \multirow{2}{*}{ Hujan } & Rendah & 0,24 & 47,61 & 58,04 \\
& Sedang & 0,53 & 58,24 & \\
& Tinggi & 0,23 & 68,75 & \\
Kemarau & Rendah & 0,13 & 52,50 & 69,33 \\
& Sedang & 0,68 & 67,33 & \\
& Tinggi & 0,19 & 84,43 & \\
\hline
\end{tabular}

Pada Tabel 3, dapat dilihat bahwa peluang untuk nilai kondisi rendah pada musim hujan adalah 0,24 , artinya sebanyak $24 \%$ atau 15 dari 62 petani yang berproduksi dengan kriteria rendah. Peluang mencapai kondisi sedang pada musim hujan adalah 0,53 , artinya sebanyak $53 \%$ atau 33 dari 62 petani yang berproduksi dengan kriteria sedang. Peluang kondisi tinggi adalah 0,23 yang berarti sebanyak 23 $\%$ atau 14 dari 62 petani responden telah berproduksi dengan kriteria tinggi. Interpretasi yang sama juga berlaku untuk persentase peluang produksi usahatani bunga pacar air pada musim kemarau.

Rata-rata produksi dengan kriteria rendah pada musim hujan diperoleh dari hasil bagi penjumlahan seluruh produksi petani yang berproduksi pada kriteria rendah pada musim hujan dengan jumlah petani yang berproduksi di kriteria rendah pada musim hujan. Interpretasi yang sama juga berlaku untuk rata-rata produksi dengan kriteria sedang dan tinggi pada musim hujan serta kriteria rendah, sedang, dan tinggi pada musim kemarau.

Perhitungan tingkat risiko produski usahatani pacar air dilihat berdasarkan produksi yang dihasilkan oleh petani pada musim hujan dan kemarau. Tingkat risiko dapat diukur dengan menggunakan, varian, standar deviasi, dan koefisien variasi yang dapat dilihat pada Tabel 4 .

Tabel 4.

Varian, Standar Deviasi, dan Koefisien Variasi Produksi Pacar Air pada Musim Hujan dan Kemarau

\begin{tabular}{lccc}
\hline \multicolumn{1}{c}{ Musim } & Varian & Standar deviasi & $\begin{array}{c}\text { Koefisien } \\
\text { variasi }\end{array}$ \\
\hline Hujan & $1.076,92$ & 32,82 & 0,57 \\
Kemarau & $1.216,96$ & 34,88 & 0,50 \\
\hline
\end{tabular}


Pada Tabel 4, terlihat bahwa nilai varian dan standar deviasi pada musim kemarau lebih tinggi dibandingkan pada musim hujan, sedangkan nilai koefisien variasi sebaliknya lebih tinggi pada musim hujan dibandingkan musim kemarau. Nilai varian dan standar deviasi pada musim kemarau lebih tinggi dibandingkan musim hujan menggambarkan sebaran data produksi lebih bervariasi antar sampel pada musim kemarau. Nilai standar deviasi pada musim hujan sebesar 32,82menunjukan sebaran data berada pada interval nilai kurang dari hingga lebih dari32,82, dari rata-rata produksi pacar air musim hujan.Nilai standar deviasi pada musim kemarau sebesar 34,88 menunjukan sebaran data berada pada interval nilai kurang dari hingga lebih dari34,88, dari rata-rata produksi pacar air musim kemarau. Semakin tinggi nilai standar deviasi berarti semakin luas interval sebaran produksi, hal ini mengidentifikasikan variasi sebaran produksi pada musim hujan lebih tinggi.

Hasil perhitungan menunjukan bahwa nilai koefisien variasi pada musim hujan lebih tinggi dibandingkan musim kemarau, yaitu sebesar 0,57 di musim hujan dan 0,50 di musim kemarau. Nilai koefisien variasi sebesar 0,57 pada musim hujan berarti bahwa setiap 100 kali panen memiliki 57kali peluang panen gagal pada musim hujan. Interpretasi yang sama juga berlaku terhadap nilai koefisien variasi pada musim hujan. Rasio risiko produksi pacar air pada musim hujan dan kemarau adalah sebesar 1,12. Nilai tersebut berarti setiap 1,12 risiko pacar air pada musim hujan setara dengan satu risiko pada musim kemarau.

\subsection{Pendapatan yang Dibebani Risiko}

Pendapatan yang dibebani terhadap risiko produksi merupakan pendapatan hasil dari harga per unit komoditi pacar air dengan jumlah produksi yang telah dikurangi dengan risiko produksi yang diperhitungkan. Rata-rata produksi bunga pacar air yang telah dibebani risiko tertinggi (variasi produksi terendah) pada musim hujan dan kemarau sebanyak 298,48 kg/luas tanam dan 470,47 kg/luas tanam. Ratarata penerimaan yang diperoleh oleh responden pada musim hujan dan kemarau sebesar Rp 3.817.729,68/luas tanam dan Rp 6.034.655,81/luas tanam.

Rata-rata penerimaan dengan risiko yang telah dibebani terhadap rata-rata total biaya menghasilkan nilai rata-rata pendapatan dengan risiko pada musim hujan dan kemarau masing-masing sebesar Rp 1.989.149,39/luas tanam dan $\mathrm{Rp}$ 4.224.599,71/luas tanam. Kondisi dengan risiko tertinggi (variasi produksi terrendah) menyebabkan 19,35 \%responden pada musim hujan dan 9,67\% responden pada musim kemarau berpeluang mengalami kerugian usahatani. 
Tabel 5.

Rekapitulasi Rata-rata Pendapatan responden yang Dibebani Risiko

\begin{tabular}{llrr}
\hline & \multicolumn{1}{c}{ Uraian } & \multicolumn{2}{c}{ Musim } \\
\cline { 3 - 4 } No & \multicolumn{1}{c}{ Hujan } & \multicolumn{1}{c}{ Kemarau } \\
\hline 1 & Rata-rata produksi (kg/luas tanam) & 710,58 & 908,44 \\
2 & Standar deviasi per responden (kg/are) & 32,82 & 34,88 \\
3 & Variasi produksi minimum (kg/luas tanam) & 298,48 & 470,47 \\
4 & Harga per unit (rp/kg) & 12.000 & 12.000 \\
5 & Rata-rata penerimaan dengan risiko (rp/lt) & $3.817 .729,68$ & $6.034 .655,81$ \\
6 & Rata-rata total biaya (rp/lt) & $1.828 .580,29$ & $1.810 .056,10$ \\
7 & Rata-rata pendapatan dengan risiko (rp/lt) & $1.989 .149,39$ & $4.224 .599,71$ \\
\hline
\end{tabular}

Pada Tabel 5, terlihat meskipun standar deviasi pada muism kemarau yang digunkan sebagai ukuran risiko lebih besar, nilai rata-rata pendapatannya juga masih lebih besar dibandingkan rata-rata pendapatan pada musim hujan.

\section{Simpulan dan Saran}

\subsection{Simpulan}

Berdasarkan hasil dan pembahasan dari penelitian yang telah dilakukan terhadap pendapatan dan risiko produksi usahatani pacar air pada musim hujan dan kemarau di Subak Saradan, Desa Sibang Gede, Kecamatan Abiansemal,Kabupaten Badung, dapat disimpulkan bahwa:

1. Pendapatan rata-rata petani pada musim hujan dan kemarau masing-masing sebesar Rp 7.226.193,90 dan Rp 9.790.798,74, dengan perbadingan 1:1,35.

2. Tingkat risiko pada musim hujan sebesar 0,57 lebih tinggi dibanding musim kemarau sebesar 0,50, dengan rasio 1,14 dilihat dari nilai koefisien variasi.

3. Pendapatan rata-rata petani yang telah dikurangi risiko produksi pada musim hujan dan kemarau masing-masing sebesar Rp 1.989.149,39 dan Rp 4.224.599,71, dengan perbandingan 1:2,12.

\subsection{Saran}

Saran yang dapat direkomendasikan adalah.

1. Usahatani pacar air sebaiknya dilaksanakan pada musim kemarau, ini didasarkan atas nilai pendapatan yang lebih tinggi serta risiko yang lebih rendah dibandingkan dengan musim hujan.

2. Petani perlu melakukan diversifikasi tanaman lain pada musim hujan untuk menggantikan komoditas pacar air, ini didasarkan atas selisih pendapatan antara musim hujan dan kemarau yang cukup tinggi. 


\section{Daftar Pustaka}

BPS. 2015. Produk Domestik Bruto Atas Dasar Harga Konstan 2000 Menurut Lapangan Usaha (Miliar Rupiah), 2000-2014. diunduh pada http://www.bps.go.id. Diakses pada: 15-08-2015.

Budiasa, I Wayan. 2011. Pertanian Berkelanjutan Teori dan Pemodelan. Udayana University Press. Denpasar.

Darmawi. 2004. Manajemen Risiko. Bumi Aksara. Jakarta.

Firdaus, Muhamad.2007. Manajeman Agribisnis. Bumi Aksara. Jember.

Nasution, Puspa Herawati. 2010. Analisis Usahatani Jamur Tiram Putih (Kasus di Komunitas Petani Jamur Ikhlas, Desa Cibening, Kecamatan Pamijahan, Kabupaten Bogor). Institut Pertanian Bogor. Bogor.

Purnama Sari, Fitria. 2012. Analisis Risiko Produksi Pembenihan Melon di CV Multi Global Agrindo, Kecamatan Karangpandan, Kabupaten Karanganyar, Jawa Tengah. Institut Pertanian Bogor. Bogor.

Salvatore, Dominick. 2003. Managerial Economics dalam Perekonomian Global Edisi Keempat Jilid 2. Erlangga. Jakarta.

Siregar, syofian. 2013. Metode Penelitian Kuantitatif (dilengkapi dengan Perbandingan Perhitungan Manual \& SPSS. Prenanda Media Grup. Jakarta.

Suharyanto, J.Rinaldy dan N.N.Arya. 2015. Analisis Risiko Produksi Usahatani Padi Sawah di Provinsi Bali. BPTP Bali. Bali.

Suryana, Sawa. 2007. Analisis Faktor-faktor yang Mempengaruhi Produksi Jagung di Kabupaten Blora. Magister Ilmu Ekonomi dan Pembangunan. Universitas Diponogoro. Semarang. 